cil" that has moved into the offices of the now disbanded Communist youth organization has said that it is not interested in politics; its main concern is protecting the students' "social interests".

Leipzig economics student Sven Biebler admits that East German students have played a much less active role in political change than their counterparts in Czechoslovakia and Romania. "The university warned us not to go to the demonstrations. in October," he said, and most of the students obeyed and "stayed passive."

Activists like Jens Reich who had hoped to see a kind of "revolutionary new university" emerge, perhaps modelled on East Germany's own universities in the very early days of the country, have been sorely disappointed.

\section{An East German Foundation?}

Science has yet to find its voice in the new East Germany. Aside from the paralysed leadership in the soon-to-be-reorganized Academy, there is no one who can speak for the concerns of basic research the way that a science minister or National Science Foundation chief can.

Those widely separated researchers who already feel the pressure of Western competition say as one that the situation for research funding is "precarious". Tom Rapoport of ZIMB says that no one from the Academy leadership has tried to attract hard currency for research, so he has had to try to find it himself. "So far, reunification is all words," he says, "but where money is concerned, it goes much more slowly".

Rapoport and others chafe at having to apply for grants only in conjunction with West German research groups from organizations like the Deutsche Forschungsgemeinschaft (DFG). They would like to see some kind of East German Science Foundation set up to award grants on a competitive, peer-reviewed basis. But where will the money come from? In the wake of the recent elections, it is too early for the politicians to offer an answer. As of 23 March, the East German Christian Democratic Union, the party that received the most votes, had yet to appoint a spokesperson for science.

DFG says that it cannot support East German groups directly until unification. But even then, say Rapoport and others, there is an obvious need for a buffer period of two to three years before the same conditions apply for all applicants.

In the meantime, there is still the risk that the best researchers will leave East Germany entirely. Although if selected groups were "tided over" by earmarked funds from the West, as some are suggesting, then suspicion will certainly grow among rivals that connections count more than scientific achievement - a bad precedent in a newborn democracy.

Steven Dickman

\title{
Ploughing a lonely furrow
}

Halle

ENSLAVED but not defeated by the scourge of Marxism-Leninism, Sanskrit scholar Johannes Mehlig of Halle has taken up the challenge, along with a small group of other academics, of restructuring the historic Martin Luther University, founded in 1694.

No stranger to oppression, Mehlig endured daily beatings as the child of a Protestant minister in antireligious Nazi Germany. He suffered again for four years as a Soviet prisoner of war, beginning when he was 16 years old. After a brief flirtation with the Communist Party in the early 1950 s, Mehlig thumbed his nose at the Party, which valued loyalty more than true scholarship.

These experiences, along with his recognized accomplishments in his field, give Mehlig tremendous power in his dealings with both colleagues and adversaries. "He has a towering personality," says mathematician Heinrich Renelt of Halle.

Mehlig bears his unofficial title - the "longest-serving assistant [professor] in all of Germany" - with pride and just a trace of bitterness. Stopped early in a promising career, Mehlig was "swept into a corner" by the government, says Renelt.

It would be only a slight exaggeration to say Mehlig is East Germany's only surviving dissident. Many other intellectuals were victimized by the Party all over East Germany. But Mehlig is almost alone in his refusal to strike any compromise or to

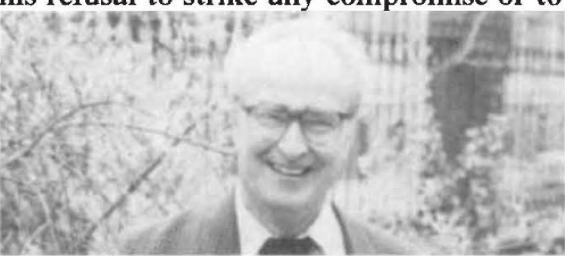
Long-suffering Johannes Mehlig . . . Now life can go on.

flee to West Germany. Hence he is one of the few people with a clean enough record to come across as a true reformer.

The main problem in the university in Halle lies in the humanities faculties, which were twisted more brutally by Communist ideology than the natural sciences. All 36 professors and lecturers in the philosophy department of the university were Communist Party members. Professors of law and economics conformed even more to the Party line, though they are now scrambling to cleanse their titles of the modifier "Marxist-Leninist."

Mehlig believes some professors could be rehabilitated, possibly by sending them to the West for a year or two, "but that there can be no pardon" for those who were guilty of "criminal acts" such as denouncing critical students or colleagues. "A teacher must be able to stand up in front of his students and be morally credible," he says.

The "Initiative Group for Renewal of the Martin Luther University" has come only a very short way in the monumental task at hand. For example, it recently discovered that the university had maintained 15 apartments in Halle used by the dreaded Stasi, the secret police, for spying. When confronted with the evidence, the entire Senate of the university, which advises its rector, resigned.

"It's important that Mehlig stays here and stays healthy," says Renelt, who is also a member of the initiative group. "So many of the reforms here stand and fall with him." Without Mehlig, says Renelt, the rector "would not have even spoken to us."

Mehlig's rejection of Communism in 1952 came at the height of the Stalin era, when universities were expected to produce "good comrades" rather than good researchers. In 1965, he turned down an offer to become a faculty member at the university in nearby Leipzig . "I would have had to become a Marxist-Leninist Sanskritist," explains Mehlig, "which does not and cannot exist. And I would have had to deal on an equal basis with colleagues who I knew had sold out to the Stasi." Mehlig had several more scrapes with the Communist authorities before he was finally given a lifetime hold on his lowly position in the university reform of 1968. An old Jewish professor in Halle, Heinz Mode, "saved my neck by sticking me in the closet", says Mehlig. "He brought me into the department of Oriental archaeology, where they had never had a philologist before." Were it not for Mode, Mehlig believes he would not have been able to remain at university at all.

"But when Mode tried to get me a lectureship in 1967," he says, "I was denounced to the Education Ministry, which was only too happy to turn down the application. I later discovered that one of my students was blackmailed by the Stasi into denouncing me," he adds.

A ban on his publishing was lifted in 1979 after 11 years, says Mehlig, when the regime discovered that his books on Buddhism and India could be sold in the West for hard currency. One book, Buddhist Fairy Tales, sold 45,000 copies.

As well as helping to reorganize the university, Mehlig, now a grandfather, is intent on achieving the status - a full professorship, with freedom to travel that he was denied for 35 years under the Communists.

Despite all he has gone through, Mehlig insists he is not bitter. "Ask my family", he says. "They always scolded me for being so optimistic. This is partly because of Buddhism, my adopted religion. But as long as 30 years ago, I realized that as soon as the Russians discovered East Germany was a burden, they would drop it like a hot potato. And then life could go on." S.D. 